\title{
Glaciological observations in 2012 and 2013 at SIGMA-A site, Northwest Greenland
}

\author{
Satoru YAMAGUCHI ${ }^{1}$, Sumito MATOBA ${ }^{2}$, Tetsuhide YAMAZAKI $^{3}$, Akane TSUSHIMA ${ }^{4}$, \\ Masashi NIWANO ${ }^{5}$, Tomonori TANIKAWA ${ }^{6}$ and Teruo AOKI ${ }^{5}$ \\ 1 Snow and Ice Research Center, National Research Institute for Earth Science and Disaster Prevention, Nagaoka, 940-0821, Japan \\ *yamasan@bosai.go.jp \\ 2 Institute of Low Temperature Science, Hokkaido University, Sapporo, 060-0819, Japan \\ 3 Avangnaq, Takatsuki, 569-0094, Japan \\ 4 Graduate School of Environmental Science, Hokkaido University, Sapporo, 060-0810, Japan \\ 5 Meteorological Research Institute, Tsukuba, 305-0052, Japan \\ 6 Japan Aerospace Exploration Agency, Tsukuba, 305-8505, Japan
}

(Received May 7, 2014; Revised manuscript received July 17, 2014)

\begin{abstract}
Glaciological observations were conducted in 2012 and 2013 at the SIGMA-A site on the northwest Greenland ice sheet (78 03’06”N, 67 37'42”W, $1490 \mathrm{~m}$ a.s.l.) as part of the Snow Impurity and Glacial Microbe effects on abrupt warming in the Arctic (SIGMA) project. The meteorological conditions during the two observations were quite different. The meteorological condition during the 2012 observation period was warm, and heavy rainfall occurred during the observation period, thus the snow was very wet. In contrast, the meteorological condition during the observation period in 2013 was cold, with a blowing snow event, thus the snow was quite dry.

The glaciological observations in 2012 consisted of 1) snow-stake measurements, 2) snow pit observations, 3) grain size observations for validation of satellite-derived snow products, 4) snow specific surface area measurements using a near-infrared camera, 5) snow sampling for chemical analyses, and 6) drilling of firn cores with a hand auger. The glaciological observations in 2013 consisted of 1) snow-stake measurements, 2) snow pit observations, and 3) snow sampling for chemical analyses.
\end{abstract}

Key words: SIGMA project, SIGMA-A, glaciological observation, snow property, accumulation area in northwest Greenland

\section{Introduction}

The Greenland ice sheet is presently undergoing drastic changes (Steffensen et al., 2008; van den Broeke $e$ t al., 2009; Rignot et al., 2011). One of the possible drastic changes in the accumulation areas in Greenland is "positive albedo feedback (Box et al., 2012)," namely, an increase in snow grain size due to acceleration of snow metamorphism, thus reducing the albedo when the air temperature increases. To elucidate the snow/ice albedo feedback effect caused by snow grain growth and light-absorbing snow/ice impurities, including glacial microbes, the Snow Impurity and Glacial Microbe effects on abrupt warming in the Arctic (SIGMA) project was launched in 2011 (Aoki et al., 2014a). As part of the SIGMA project, an automatic weather station (AWS) was established in the accumulation area on the northwest Greenland ice sheet (78 $03^{\prime} 06^{\prime} \mathrm{N}, 67^{\circ} 37^{\prime} 42^{\prime \prime W}, 1490 \mathrm{~m}$ a.s.l.), which was named "SIGMA-A site" (Fig. 1), and field campaigns for glaciological observations at SIGMA-A site were conducted in 2012 and 2013 (Aoki et al., 2014a).

The 2012 glaciological observation was conducted at SIGMA-A site from June 26 to July 16, 2012. The meteorological conditions during the first half of this observation period (June 26 to July 9, 2012) were relatively warm (average air temperature was $-0.2^{\circ} \mathrm{C}$ ), while heavy rainfall (60 to $100 \mathrm{~mm}$ ) occurred from July 10 to July 13, 2012, in the second half (average air temperature was $1.3^{\circ} \mathrm{C}$ ) (Aoki et al., 2014a). During the same period of observation in 2012, a record melting event of surface snow/ice was observed over the Greenland ice sheet (Nghiem et al., 2012; Tedesco et al., 2013).

The 2013 glaciological observations were conducted at SIGMA-A site from July 23 to July 30, 2013. The monthly average air temperature in July 2013 was approximately $4^{\circ} \mathrm{C}$ colder than that in July 2012, and heavy blowing snow occurred during the observation period in 2013. There was thus a large difference between the meteorological conditions during the glaciological observations in 2012 and 2013. The aim of this paper is to present the preliminary results of 


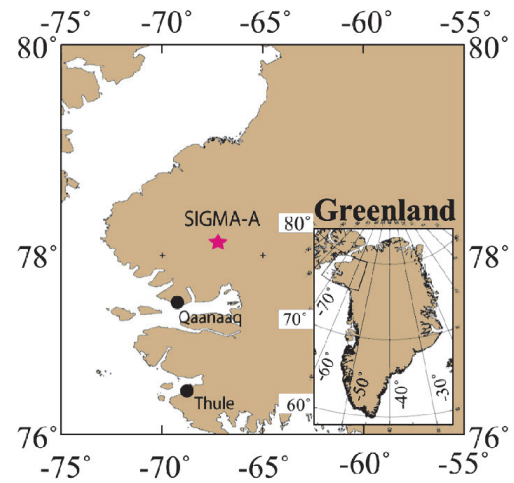

Fig. 1. Map showing the location of SIGMA-A site $\left(78^{\circ}\right.$ 03’06” N, 67³7'42”W, $1490 \mathrm{~m}$ a.s.l.).

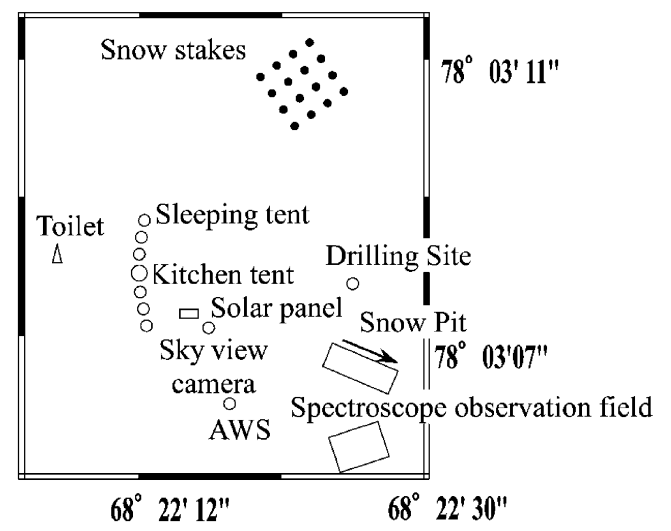

Fig. 2. Location of observation sites in 2012 at SIGMA-A site.

glaciological observations in 2012 and 2013 at SIGMA-A site for further studies.

\section{Glaciological observations in $\mathbf{2 0 1 2}$}

\subsection{Snow-stake measurements}

A snow-stake network was established on June 30, 2012 (Fig. 2) consisting of 16 snow-stakes from Japan, made of bamboo, approximately $2 \mathrm{~m}$ in length. The snow-stakes were inserted into the snow cover until they reached a thick ice layer at approximately $80 \mathrm{~cm}$ below the snow surface (the average value was $82.4 \mathrm{~cm}$ with a standard deviation of $\pm 27.1 \mathrm{~cm}$ ). Each height from the snow surface to the top of the snow-stake $(h)$ was measured each day at 9:00 a.m. from June 30 to July 13, 2012. Then, the surface lowering $\Delta h(\mathrm{~cm})$, which is the difference between the $h$ value of the previous day and the present day, was calculated.

Fig. 3a shows the values of $\Delta h_{\text {ave }}$, which is the $\Delta h$ averaged over all the snow-stake data at each measurement. Because the $\Delta h$ values showed a small fluctuation at each stake, the dispersion of the data is also shown by bars. Data from July 13, which is shown in a different color, had different measurement intervals due to lack of data on July 11 and 12 because of heavy rainfall (Aoki et al., 2014b); namely, the value consists of the cumulative data from three days, July 11 to July 13. The fluctuation
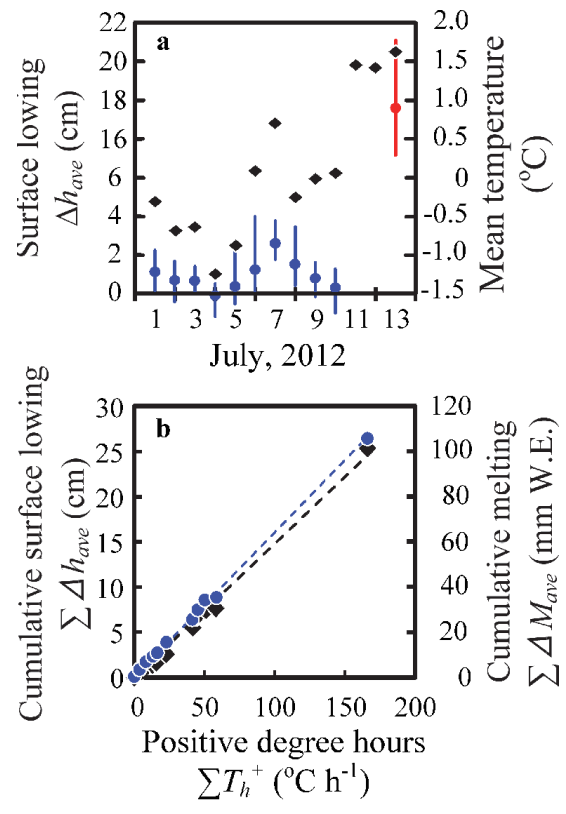

Fig. 3. Results of snow-stake observations in 2012.

a. Results of daily surface lowering and mean air temperature. Blue circles indicate the averaged surface lowering over all measurements from 9:00 a.m. of the previous day to 9:00 a.m. of the present day. Red circle indicates the averaged cumulative surface lowering from 9:00 a.m. on July 10 to 9:00 a.m. on July 13. Bars indicate the dispersion of the data. Black rhombuses indicate the mean air temperature during each observation interval.

b. The relationship between positive degree hours and cumulative surface lowering or cumulative melting. Blue circles indicate the cumulative value of surface lowering since June 30, 2012. Black rhombuses indicate the cumulative value of melting estimated using the measured surface density.

of mean air temperature from 10:00 a.m. of the previous day to 9:00 a.m. of the present day, which was measured at $3 \mathrm{~m}$ height at the AWS of SIGMA-A (Aoki et al., 2014a), is also shown in Fig. 3a. Although the mean air temperature were sometimes negative, there was a good correlation between the surface lowering and mean air temperature; large surface lowering occurred when the mean air temperature was high.

The surface lowering should include the following three pieces of information: 1) erosion by wind, 2) melting, and 3) settling of the surface due to compression by snow cover. We considered that the effect of the erosion should be neglected because of the wet snow surface condition. Although it was difficult to estimate surface settling from the observation data, and the numerical snow cover simulation should be examined to evaluate the amount of surface settling, we deemed that the influence of surface settling on $\Delta h$ was small because no snowfall occurred, and the densities of the snow cover were relatively high during the observation period.

In general, the amount of melt showed good correlation with the cumulative positive daily mean temperature (Positive Degree Day, PDD) (e.g., Ohmura, 2001). 
Because the period of our data was limited, we introduced the idea of positive degree hours $\left(\sum T_{h}{ }^{+}\right)$, which is essentially the same as PDD, namely, the sum of positive hourly air temperatures during the observation period $\left({ }^{\circ} \mathrm{C}\right.$ h). Fig. 3 b shows the relationship between the cumulative $\Delta h_{\text {ave }}\left(\Sigma \Delta h_{\text {ave }}\right)(\mathrm{cm})$ and $\Sigma T_{h}{ }^{+}$during the observation period. There is a high linear correlation between $\sum \Delta h_{\text {ave }}$ and $\Sigma T_{h}{ }^{+}$, as shown by the following equation:

$$
\sum \Delta h_{\text {ave }}=0.16 \sum T_{h}^{+}(R=0.99),
$$

where $R$ is the correlation coefficient.

The values of the average melting $\left(M_{\text {ave }}\right)$ at each $\Delta h_{\text {ave }}$ were estimated using the measured surface density data, then the cumulative $M_{\text {ave }}\left(\Sigma \Delta M_{\text {ave }}\right)$ ( $\mathrm{mm}$ for water equivalent, W.E.) during the observation period was also calculated (Fig. 3b). There is also a high linear correlation between $\Sigma \Delta M_{\text {ave }}$ and $\Sigma T_{h}{ }^{+}$, as shown by the following equation:

$$
\sum \Delta M_{\text {ave }}=0.59 \sum T_{h}{ }^{+}(\mathrm{R}=0.99) .
$$

Here, it must be noted that $M_{\text {ave }}$ may not be equal to ablation because there is the possibility of internal accumulation of meltwater, such as superimposed ice formation, which we will discuss in section 2.2, "Snow pit observations."

\subsection{Snow pit observations}

Standard snow pit observations were carried out at approximately 10:00 a.m. from June 30 to July 13, 2012. The observation items were snow stratigraphy (grain shape $F$ and grain size $E$ ), snow density $\rho$, snow temperature $T$, mass liquid water content $(L W C)$ calculated from a dielectric measurement (Denoth et al., 1984) and $\rho$, and water equivalent of all layers above a thick ice layer, which will be discussed later, using a snow sampler. The snow pit observations followed the methodology outlined by the Nihon Seppyo Gakkai (2010).

A thick ice layer, which was too hard to penetrate, was found $88 \mathrm{~cm}$ below the surface during the first snow pit observation on June 30. The layers above the thick ice layer were essentially dry, except for a few layers near the surface which were probably caused by a melting event in very recent days. This result implies that melting events did not occur after accumulation of snow above the thick ice layer, except for recently on June 30 . On the other hand, the pit observation data on July 30 , 2011 at $1469 \mathrm{~m}$ a.s.l., which is almost the same altitude as SIGMA-A, showed the existence of thick melt forms layers ( $85 \mathrm{~cm}$ thick) due to large melting events (Aoki et al., 2014a). In addition to this observation result, the layer just above the thick ice layer consisted of a developed depth hoar, which indicated a record high temperature gradient after accumulation of this layer (Akitaya, 1974). Based on previous studies of development of depth hoars overlying wet snow (e.g. Fukuzawa and Akitaya, 1993; Jamieson and Fierz, 2004), we considered that this depth hoar layer developed from a layer overlying the snow surface of the previous summer, which
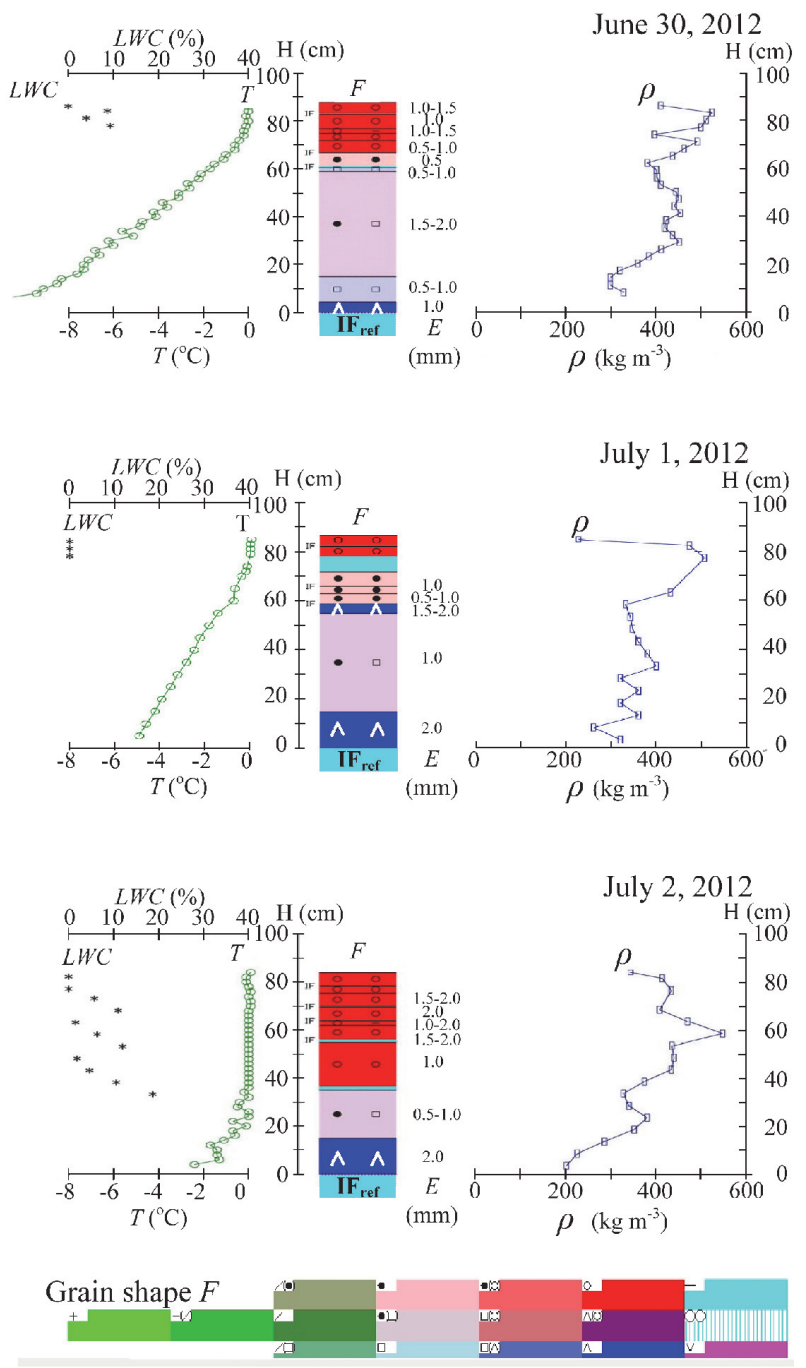

Fig. 4. Snow pit observations in 2012.

The colors and symbols representing snow classifications are in accordance with the snow classification system of Fierz et al. (2009). $\quad F$ is grain shape, $E$ is grain size, $L W C$ is mass liquid water content, $T$ is snow temperature, and $\rho$ is snow density.

must have been wet. For these reasons, we finally concluded that this thick ice layer was the reference surface of the previous summer surface, and all snow pit observations were conducted for the snow cover above this thick ice layer $\left(\mathrm{IF}_{\text {ref }}\right)$. Our assumption that $\mathrm{IF}_{\text {ref }}$ was the previous summer surface was supported by the result of chemical analyses of the snow pit described in section 2.5, "Snow sampling for chemical analyses." An approximately $1.5 \mathrm{~m}$ wide pit was dug on June 30 , and the pit was expanded forward at least $1 \mathrm{~m}$ from the previous pit wall at each observation (Fig. 2).

Fig. 4 shows the measurement results at each snow pit observation, in which snow heights $(\mathrm{H})$ are defined as the height from $\mathrm{IF}_{\text {ref. }}$ The distributions of snow temperature and grain shape in the first half-period (June 30 to July 5), except for the data from July 2 and 3, indicated that melting did not dominate during this period because of low temperatures (Fig. 3a). The data from July 2 and 3 showed that the snow temperature during the most 

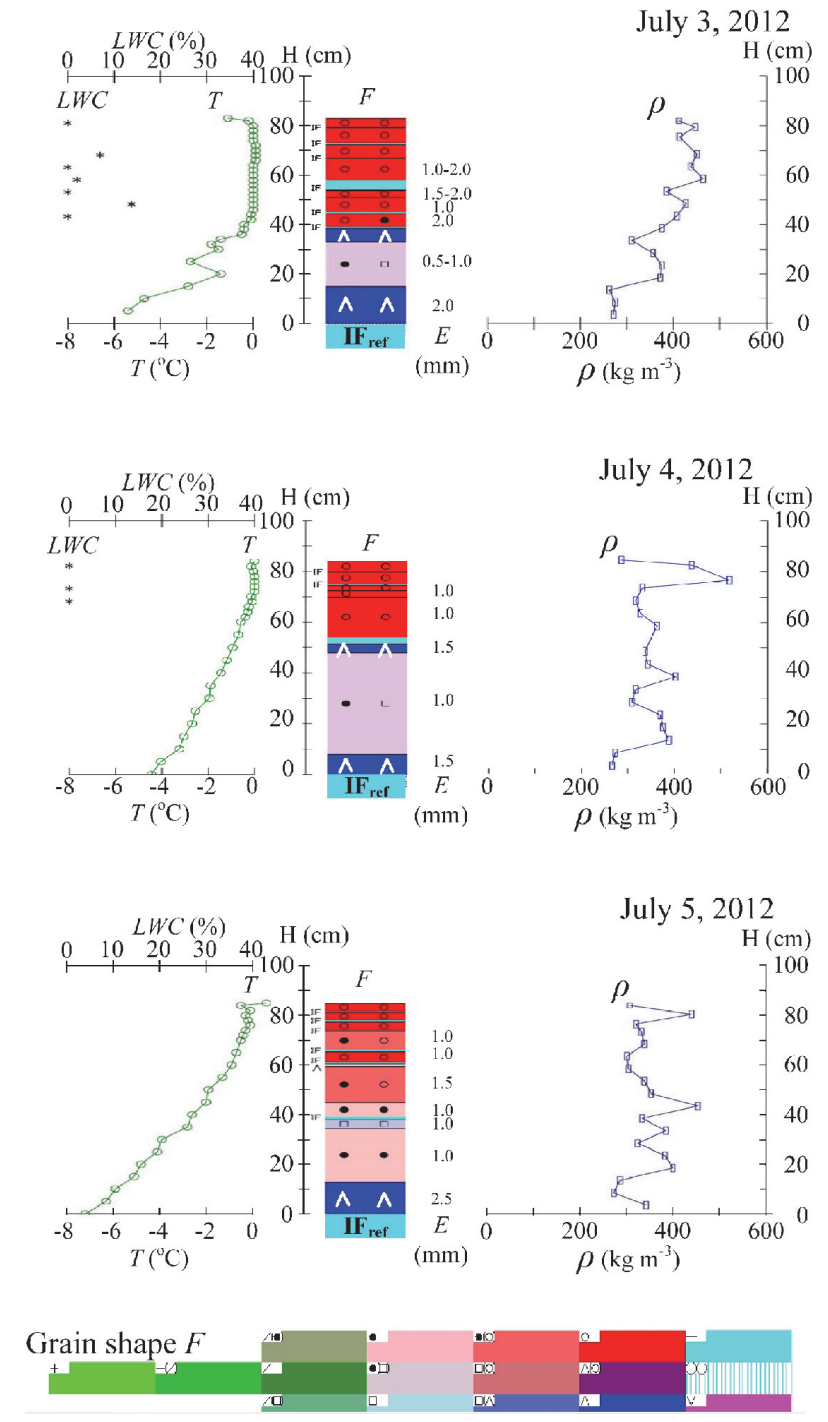

Fig. 4. Continued.

snow cover was $0^{\circ} \mathrm{C}$, and the dominant grain shapes were melt forms, which should have been affected by the existence of a water pass because the snow stake observations showed that remarkable melting (surface lowing) did not occur during this period (Fig. 3a). After July 6, the snow temperature was $0^{\circ} \mathrm{C}$ from the top, and the $0^{\circ} \mathrm{C}$ position reached the bottom on July 10 because the mean air temperature during this period became positive (Fig. 3a).

Fig. 5 shows the ratios of melt forms, including ice layers and dry grain shapes. In this analysis, layers that had two grain shapes, melt forms and dry grain shapes, were classified as melt forms layers. The ratio of melt forms increased with time, and all layers became melt forms after the heavy rainfall event on July 10-13 (Aoki et al., 2014b).

Fig. 6 shows the values of the water equivalent $(\mathrm{mm}$ W. E.) of snow cover above the $\mathrm{IF}_{\text {ref }}$ measured using a snow sampler and estimated using the distribution of snow density measured during each snow pit observation. Essentially, the value measured using the snow sampler was smaller than that estimated from the distribution of
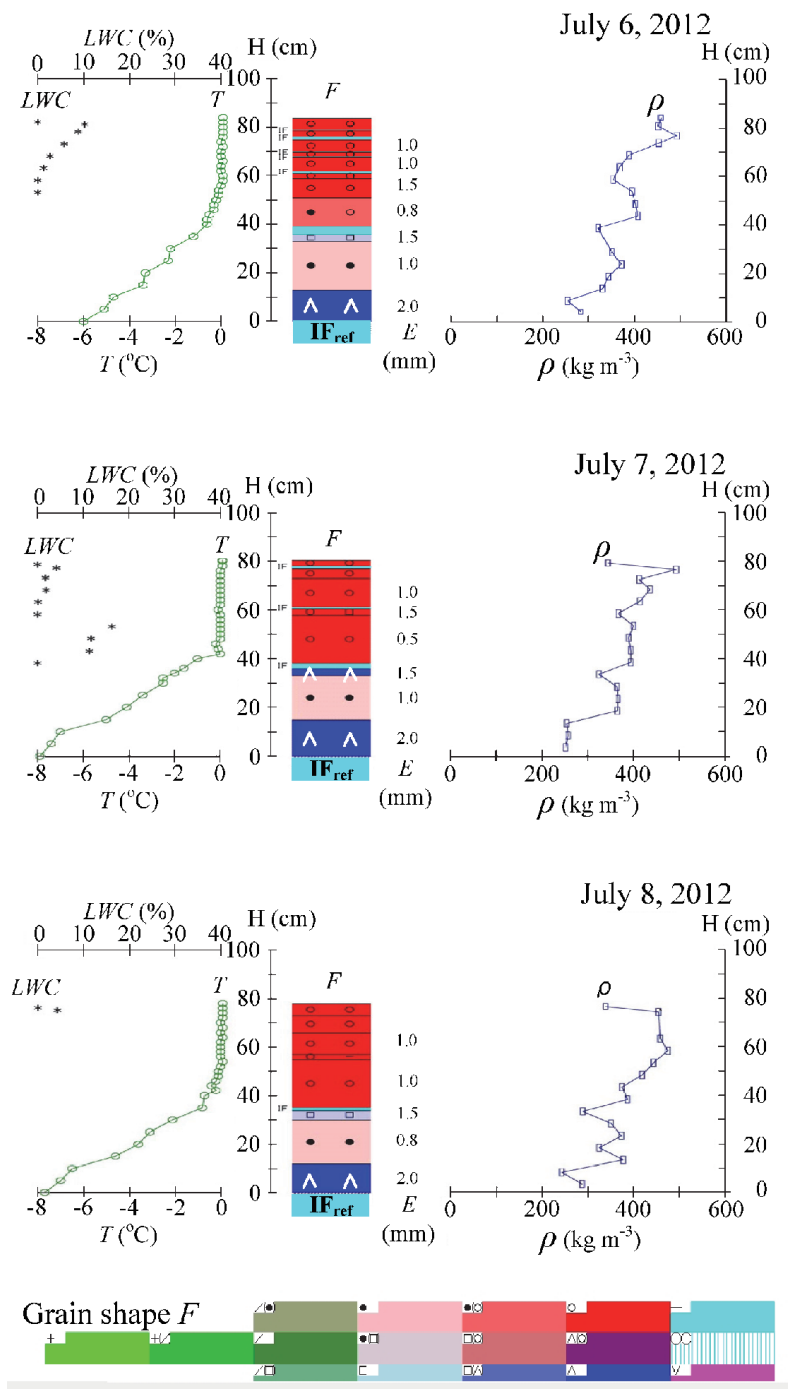

Fig. 4. Continued.

snow density during the snow pit observation. It is not clear why the values from the snow sampler were smaller than those estimated from the distribution of snow density, but one possibility is that the snow sampler measurement did not catch a part of the depth hoar layer on the $\mathrm{IF}_{\text {ref, }}$ which was very fragile. It is notable that both estimation methods showed a gradual decrease of the water equivalent of snow cover with time. Two possible explanations for the decrease of the water equivalent of snow cover with time should be considered. The first possible explanation is the discharge of meltwater from the area. We considered this possibility to be small because the complete impermeable layers that are needed to make aquifers for large horizontal movement of water, such as thick ice layers, were not observed except for $\mathrm{IF}_{\text {ref, }}$ although some discontinuous ice layers with melt forms were observed. Moreover, the snow cover was so cold that a large amount of water could not have moved away from the area before it was refrozen. The second possibility is that meltwater reached the $\mathrm{IF}_{\text {ref }}$ by preferred flow through water passes and refroze there (superimposed ice information). The existence of 

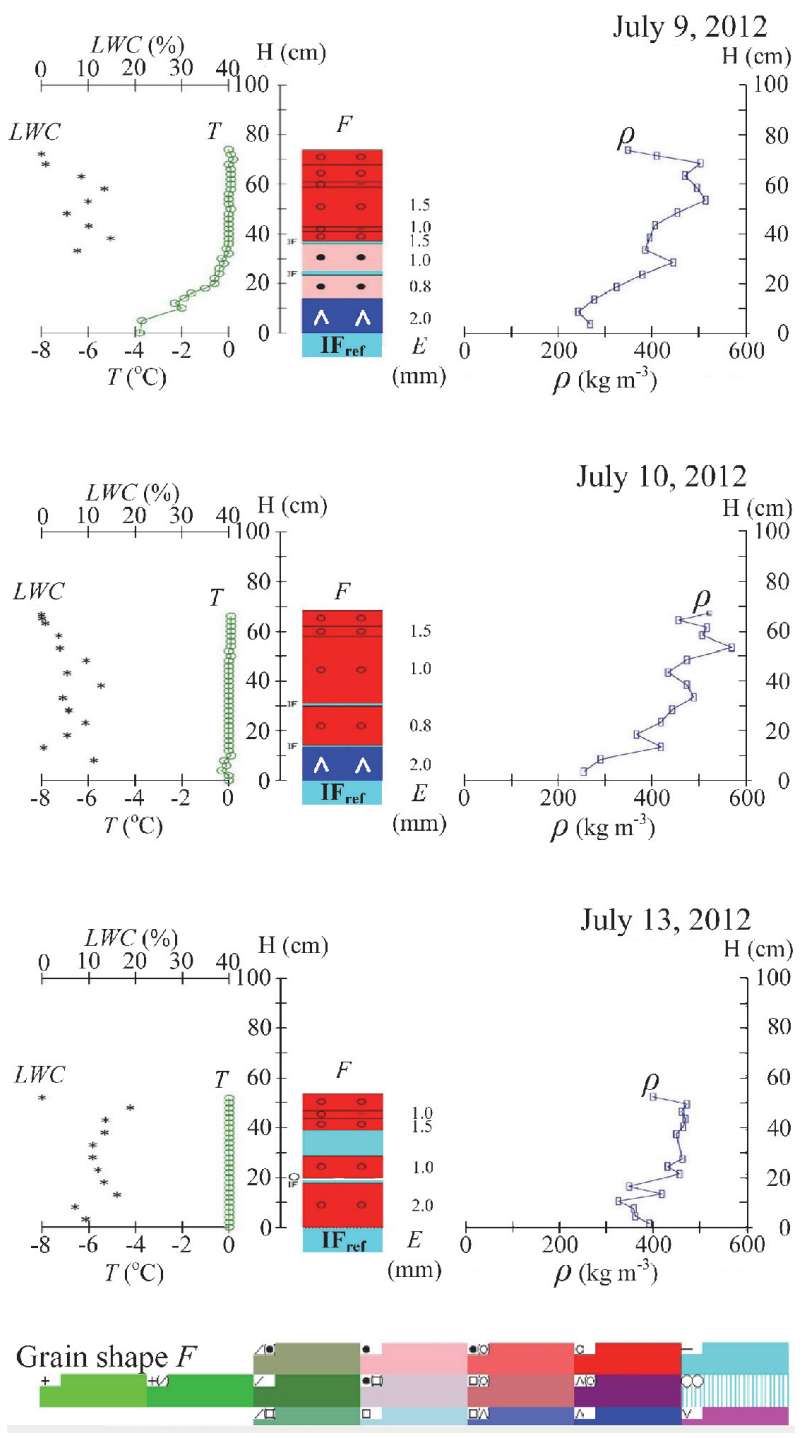

Fig. 4. Continued.

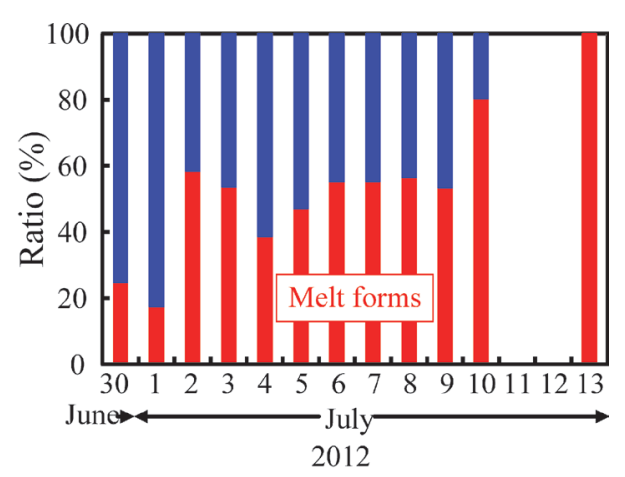

Fig. 5. The ratios of melt forms and dry grain types in 2012 . Red areas are the ratios of melt forms and blue areas are dry grain shapes.

water passes was sometimes observed, although these areas were usually avoided in order to carry out snow pit observations, and the existence of water passes was not reflected in the data from the daily snow pit observations. One indication of a water pass can be seen in the data from July 2 and 3, in which the ratios of melt forms were

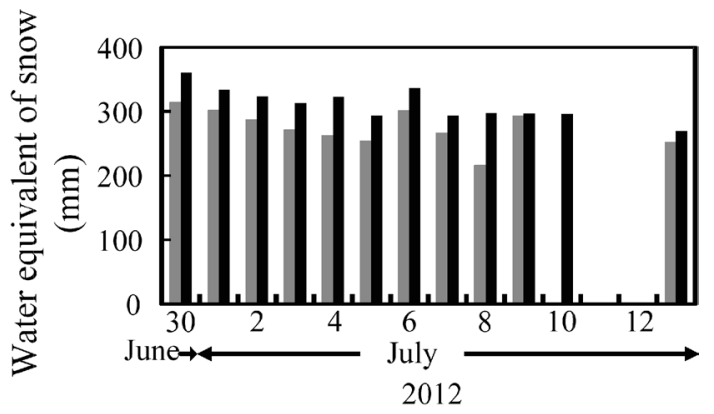

Fig. 6. Measurement results of the water equivalent of snow cover in 2012.

Gray bars indicate measured data using the snow sampler, and black bars indicate the water equivalent of snow cover using the distribution of density of the snow pit observations.
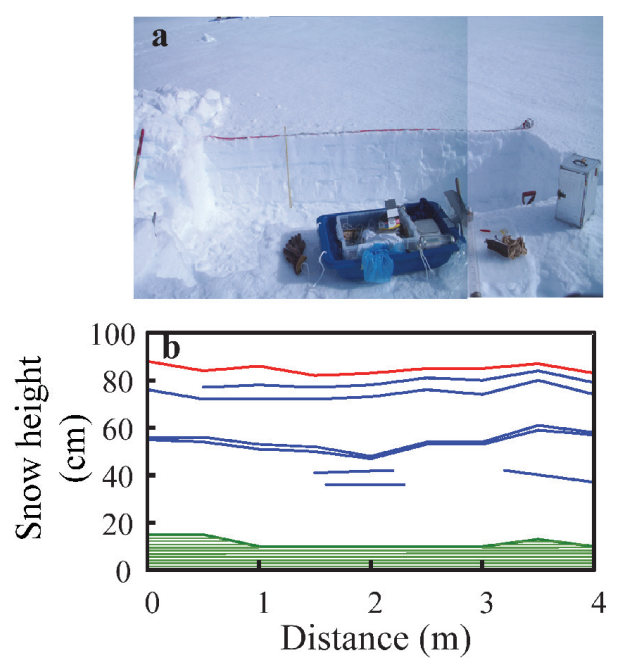

Fig. 7. Measurement results of $4 \mathrm{~m}$ wide snow pit on July 4 , 2012.

a. Photo of $4 \mathrm{~m}$ wide snow pit.

b. Horizontal variations of snow height (red line), depth hoar layer (green area), and ice layers (blue lines).

larger (Fig. 5), and the $\mathrm{IF}_{\text {ref }}$ temperature was higher than on subsequent days (Fig. 4).

The temperature of $\mathrm{IF}_{\text {ref }}$ gradually increased with time and reached $0^{\circ} \mathrm{C}$. This trend may have resulted from the heat generated by refreezing water on the $\mathrm{IF}_{\text {ref }}$. For these reasons, we considered that the cause of the decrease of the water equivalent of snow cover with time is the surface position change of $\mathrm{IF}_{\text {ref }}$ due to superimposed ice formation on the $\mathrm{IF}_{\text {ref, }}$ which was not taken into account in the snow sampling and snow pit observations. However, there is no direct evidence of superimposed ice formation, thus our discussion calls for further analyses, such as using a numerical snow cover model.

To examine the horizontal variation of snow structure, a $4 \mathrm{~m}$ wide snow pit observation was conducted on July 4, 2012 (Fig. 7). In the snow pit observation, the distributions of snow surface height from the $\mathrm{IF}_{\text {ref }}$ and the height of the top of the depth hoar layer on the $\mathrm{IF}_{\text {ref }}$ were measured with a $0.5 \mathrm{~m}$ horizontal resolution, and the 
Table 1. Horizontal variations of measured snow densities from a $4 \mathrm{~m}$ wide snow pit observed on July 4, 2012. Values in parentheses indicate standard deviations.

\begin{tabular}{|c|c|c|c|c|c|c|}
\hline Position & \multicolumn{3}{|c|}{$\begin{array}{c}\text { Near surface of snow cover } \\
\text { (Position measured from the } \\
\text { surface) }\end{array}$} & \multicolumn{3}{|c|}{$\begin{array}{c}\text { Inner part of snow cover } \\
(\text { Position measured from the } \\
\left.\text { top of } \mathrm{IF}_{\text {ref }}\right)\end{array}$} \\
\cline { 2 - 7 } & $0-3 \mathrm{~cm}$ & $2-5 \mathrm{~cm}$ & $7-10 \mathrm{~cm}$ & $62 \mathrm{~cm}$ & $40 \mathrm{~cm}$ & $17 \mathrm{~cm}$ \\
\hline $\begin{array}{c}\text { Density } \\
\left(\mathrm{kg} \mathrm{m}^{-3}\right)\end{array}$ & $\begin{array}{c}362 \\
( \pm 40)\end{array}$ & $\begin{array}{c}425 \\
( \pm 9)\end{array}$ & $\begin{array}{c}426 \\
( \pm 14)\end{array}$ & $\begin{array}{c}410 \\
( \pm 25)\end{array}$ & $\begin{array}{c}386 \\
( \pm 17)\end{array}$ & $\begin{array}{c}369 \\
( \pm 21)\end{array}$ \\
\hline
\end{tabular}

horizontal distributions of each ice layer were also measured (Fig. 7). Here, it must be noted that the following discussion is based on the assumption that $\mathrm{IF}_{\text {ref }}$ has a flat level throughout the $4 \mathrm{~m}$ wide snow pit. We regard this assumption to be reasonable, although the exact level of $\mathrm{IF}_{\text {ref }}$ was not measured. The snow height averaged over a width of $4 \mathrm{~m}$ was $84.8 \mathrm{~cm}$, with a standard deviation of $\pm 1.9 \mathrm{~cm}$, and the height of the top of the depth hoar averaged over $4 \mathrm{~m}$ was $11.4 \mathrm{~cm}$, with a standard deviation of $\pm 1.1 \mathrm{~cm}$. These horizontal variations in the snow pit observations were negligible. Some ice layers persisted throughout the $4 \mathrm{~m}$ width, but other ice layers appeared and disappeared in the $4 \mathrm{~m}$ interval. Moreover, the positions of the ice layers fluctuated up and down, even when they were persistent. These results imply that the distributions of ice layers were strongly affected by the local degree of water penetration. Thus, interpretation of the distribution of ice layers in the snow pit observation data needs to consider local influences.

Table 1 shows the variations of snow densities at several heights, measured with $1 \mathrm{~m}$ horizontal resolution. The snow density at $0-3 \mathrm{~cm}$ from the surface showed large variations, with a standard deviation of $11 \%$ for the averaged value, while other snow densities showed small variations, with a standard deviation of less than $6 \%$ of the averaged values. These results indicate that the surface conditions varied widely.

\subsection{Grain size observations for validation of satellite- derived snow products}

In addition to traditional grain size (Fierz et al., 2009), detailed grain size observations near the surface were conducted because one of the aims of the glaciological observations at SIGMA-A site was the validation of satellite-derived snow products (Aoki et al., 2007; Hori et al., 2007; Stamnes et al., 2007). To compare the optical properties of snow and measured grain size in the field, Aoki et al. (2007) proposed three definitions of grain size in field observations: $d_{1}$, the length of the major axis of crystals or dendrites; $d_{2}$, the branch width of dendrites or the width of a narrower portion of broken crystals; and $d_{3}$, the thickness of plate-like crystals. Aoki et al. (2007) also reported that $d_{2}$ generally corresponds to the optical grain size $\left(d_{o p t}\right)$. In the detailed grain size observations, maximum, minimum and medium $d_{2}$ values were measured at three positions $(0-2 \mathrm{~cm}, 2-5 \mathrm{~cm}$, and $5-10 \mathrm{~cm}$
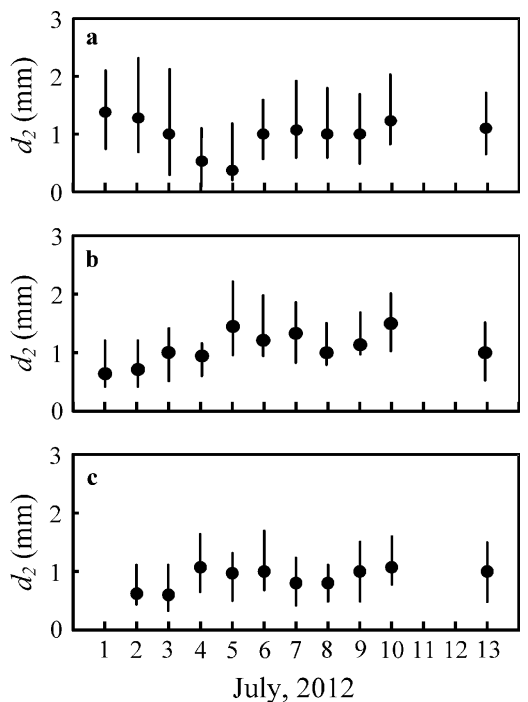

Fig. 8. Measurement results of $d_{2}$ near the surface in 2012. Black circles indicate the medium values at each measurement position. Bars indicate the range of $d_{2}$ from maximum to minimum

a. Data at $0-2 \mathrm{~cm}$ depth from the surface.

b. Data at $2-5 \mathrm{~cm}$ depth from the surface.

c. Data at 5-10 cm depth from the surface.

from the surface) using a hand held lens.

Fig. 8 shows the fluctuation of $d_{2}$ during the observation period. In the figure, the maximum to minimum ranges of $d_{2}$ are shown by a bar. The values of $d_{2}$ at all depths fluctuated around $1.0 \mathrm{~mm}$, except for the measurement at $0-2 \mathrm{~cm}$ on July 4 and 5 . The data on July 4 and 5 showed a smaller value of $d_{2}$ than other data because of the developing surface hoar (Hori et al., 2014).

\subsection{Snow specific surface area measurement using a near-infrared (NIR) camera}

Recently, optical methods based on the near-infrared reflectance value (Ref) have been used to measure the specific surface area (SSA) of snow in the field (e.g. Matzl and Schneebeli, 2006; Gallet et al., 2009; Arnaud et al., 2011; Zuanon, 2013). During the glaciological observation in 2012, one of the optical methods, namely, the NIR photometry method using around $900 \mathrm{~nm}$ wavelength light (Matzl and Schneebeli, 2006), was introduced for measuring the SSA of snow in the field. Detailed descriptions of NIR photometry have been provided by Matzl and Schneebeli (2006) and Yamaguchi et al. (2014). 

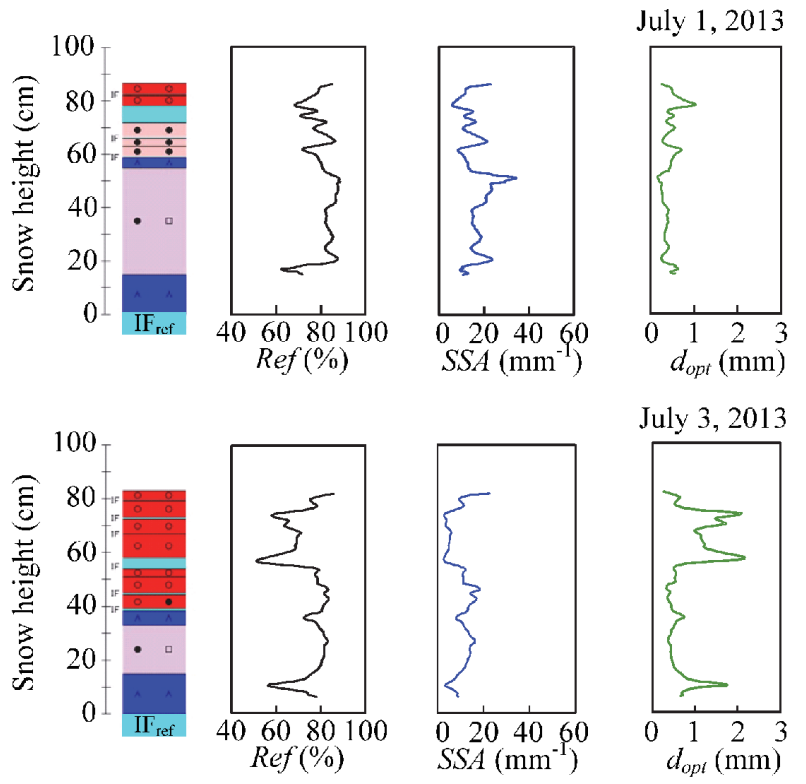

July 3, 2013

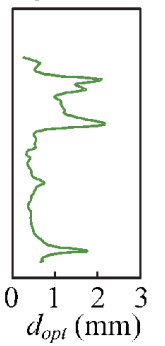

July 5,2013
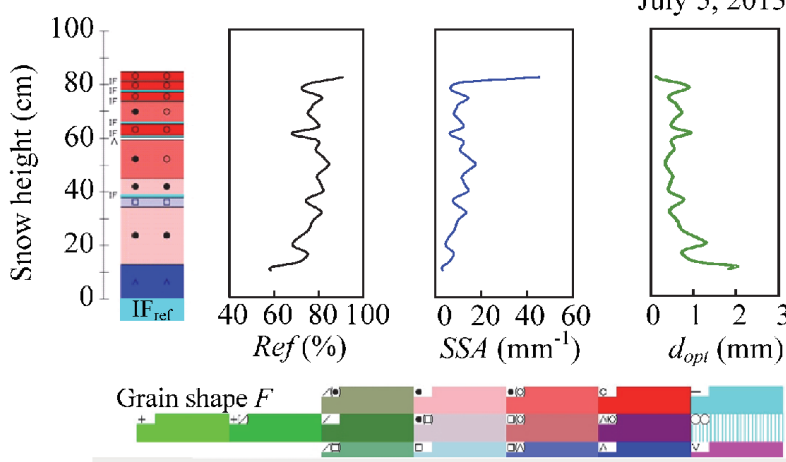

Fig. 9. Comparisons between pit observations and results using NIR photometry in 2012.

Black lines represent the measured reflectance (Ref). Blue lines represent SSA calculated using Ref. Green lines represent the calculated optical grain sizes $\left(d_{o p t}\right)$ using SSA. The colors and symbols representing the snow classifications are in accordance with the snow classification system of Fierz et al. (2009).

Digital photographs for analyses of SSA were taken every other day using a Nikon D3S, which was improved to detect near-infrared areas with a 25-mm Zeiss ZF-IR lens and gelatin filter (X-Nite $850 \mathrm{~nm}$ Filter) that selected wavelengths from 840 to $940 \mathrm{~nm}$.

Fig. 9 shows the distribution of reflectance (Ref: \%), calculated SSA $\left(\mathrm{mm}^{-1}\right)$ using measured Ref, and optical grain size $\left(d_{o p t}: \mathrm{mm}\right)$ estimated from SSA $\left(d_{o p t}=6 / \mathrm{SSA}\right)$. Although the data near the surface are plotted in the figure, these data may include errors because of the influence of light from the surface (Kuchiki et al., 2013), thus these data should be treated with caution during analyses. The fluctuations in SSA for each day generally agreed closely with the stratigraphy, namely, large changes in SSA (Ref) appeared at the boundaries of each layer. The values of $d_{\text {opt }}$ were usually smaller than grain size $(E)$ from the snow pit observation (Fig. 4), and should correspond to different definitions of grain size, as has been reported by several researchers (e.g. Grenfell and

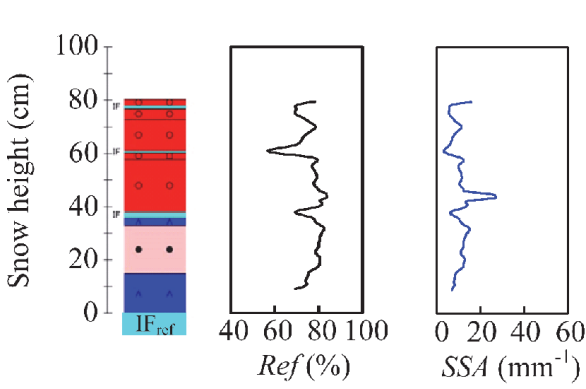

July 7, 2013

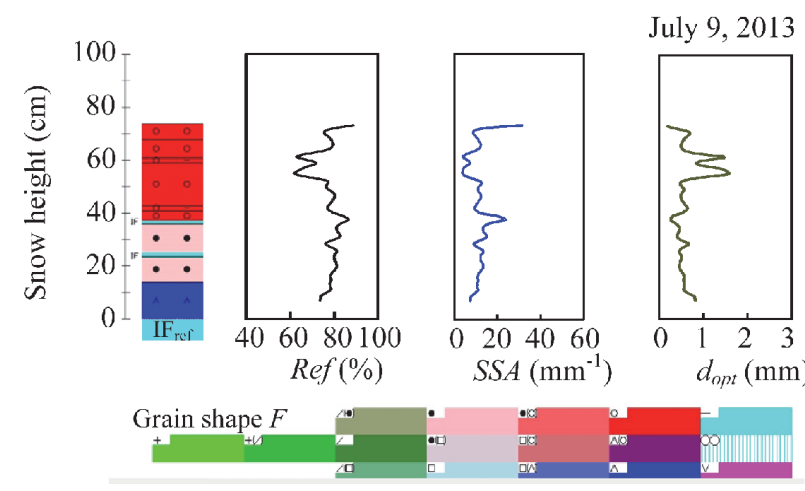

Fig. 9. Continued.

Warren, 1999; Mitchell, 2002; Langlois et al., 2010).

\subsection{Snow sampling for chemical analyses}

The stable isotope composition of precipitation is controlled by variations in the origin of the water and the condensation history during atmospheric transport, and the chemical composition of precipitation is controlled by its source and the history of scavenging processes and chemical reactions during atmospheric transport. Therefore, vertical profiles of the stable isotope and chemical composition of surface snow on the Greenland ice sheet can provide valuable information relating to the temporal variations of transport processes of water vapor and aerosols over the Greenland ice sheet.

Snow samples for chemical analyses were collected on June 30, 2012, from the snow pit wall using a stainless steel tool to transfer snow into polyethylene bags. The snow samples were melted at ambient temperature in a camping tent and then transferred into $10 \mathrm{~mL}$ polypropylene bottles. The liquid samples were then transported to the Institute of the Low Temperature, Hokkaido University, Japan.

The $\delta \mathrm{D}$ values were measured by a cavity ringdown spectroscopy (model L2130-i, Picarro) with a vaporizer (model A0212, Picarro). The typical analytical precision was $\pm 0.5 \%$. The concentrations of ion species were determined by ion chromatography (model DX500x, Dionex). The typical analytical precision was 10\%, and the detection limit of each species was $20 \mathrm{ppb}$.

Fig. 10 shows the vertical profiles of $\delta \mathrm{D}$ and concentrations of $\mathrm{Cl}^{-}, \mathrm{NO}_{3}{ }^{-}, \mathrm{SO}_{4}{ }^{2-}$, and $\mathrm{Ca}^{2+}$. The $\delta \mathrm{D}$ values above $66 \mathrm{~cm}$ height were high. Generally, the $\delta \mathrm{D}$ value in snow is mainly determined by the air temperature at which vapor condenses (Johnsen et al., 1989). Therefore, 


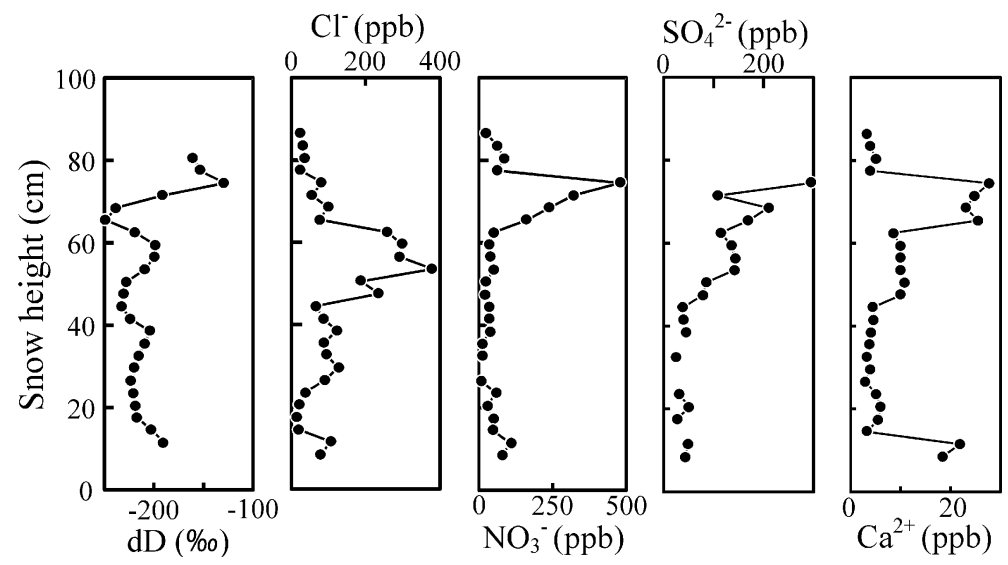

Fig. 10. Results of chemical analyses of snow samples obtained on June 30, 2012.

we assumed that the snow layer above $66 \mathrm{~cm}$ height corresponds to spring and early summer. According to the seasonally determined $\delta \mathrm{D}, \mathrm{Cl}^{-}$, which mainly originates from sea salt, showed a peak in late winter, and $\mathrm{NO}_{3}{ }^{-}$, which mainly originates from fossil fuel combustion and biomass burning, and $\mathrm{Ca}^{2+}$, which mainly originates from terrestrial dust, showed peaks in the spring and early summer. These seasonal variations of ion species are roughly consistent with those observed in the inland ice sheet (Summit) (Whitlow et al., 1992). The correspondence of seasonal variations of ion species between the coastal site (SIGMA-A) and inland suggest that aerosols deposited at SIGMA-A are supplied by long range transportation. In the figure, $\delta \mathrm{D}$ and $\mathrm{Cl}^{-}$seem to increase again near the thick ice layer $\left(\mathrm{IF}_{\text {ref }}\right)$. Moreover, $\mathrm{Ca}^{2+}$ shows another peak near the thick ice layer $\left(\mathrm{IF}_{\text {ref }}\right)$. We interpret these trends as indication that the snow cover above the $\mathrm{IF}_{\text {ref }}$ consists of one year of accumulation since the previous summer (2011).

\subsection{Firn cores drilled with a hand auger}

To reconstruct the temporal variations of mass balance, 19-m firn cores were drilled on July 3 and 6, 2012, with a hand auger designed by the technical division of the Institute of Low Temperature Science, Hokkaido University. In addition, 5.5-m firn cores were also drilled with a hand auger on July 10, to test the application of the NIR photometry method to core analyses.

The 19-m firn cores had several thick ice layers in their shallower positions from the surface (Fig. 11a), but few ice layers in the deeper positions (Fig. 11b). In fact, the melt feature percentage (MFP) of the 19-m firn-ice core shows that high MFP values appear in the upper layers above a depth of $7 \mathrm{~m} \mathrm{~W}$. E., while the MFP becomes almost zero in the deeper layers below a depth of $8 \mathrm{~m} \mathrm{~W}$. E. (Aoki et al., 2014a). This result indicated that more frequent snow melting events have occurred in recent years.

Fig. 11c shows the NIR image of the 5.5-m firn core at $2.5 \mathrm{~m}$ depth using the NIR photometry method. In the NIR Image, ice and firn are clearly distinguished, and
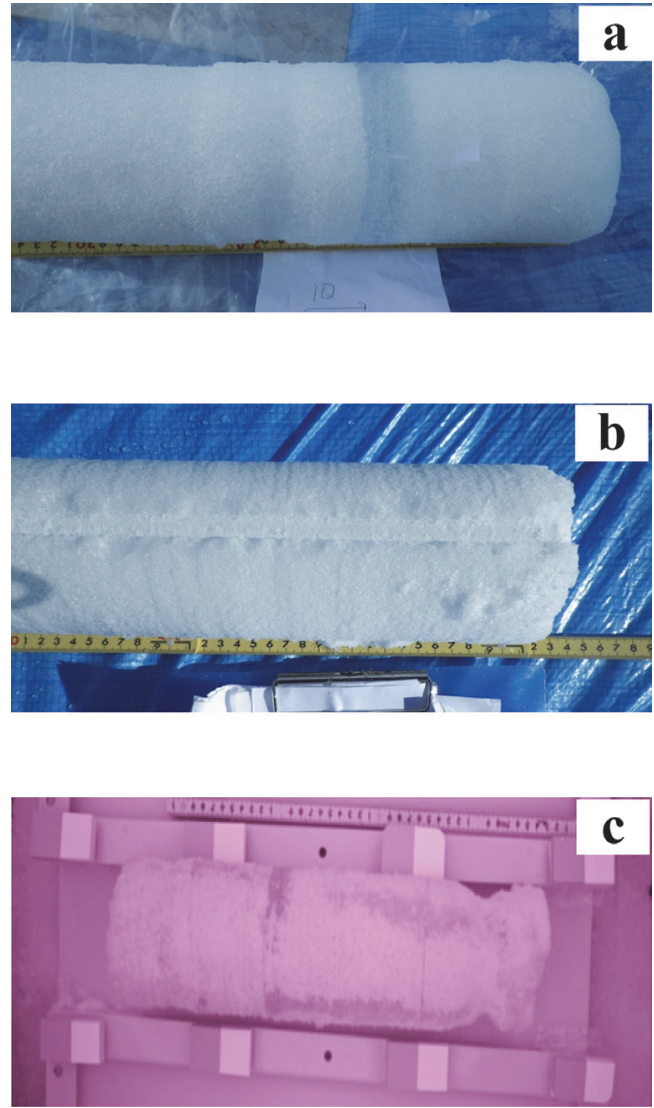

Fig. 11. Example photos of firn core obtained in 2012. a. Image of the $19 \mathrm{~m}$ firn core at $5 \mathrm{~m}$ depth (shallower layer) b. Image of the $19 \mathrm{~m}$ firn core at $15 \mathrm{~m}$ depth (deeper layer). c. Images of $5.5 \mathrm{~m}$ firn core at $2.5 \mathrm{~m}$ depth using the NIR photometry method. The diameter of the core is $10 \mathrm{~cm}$.

detailed distributions of ice in the firn are also shown. This result implies that the NIR photometry method is useful for firn core analysis (e.g., quantitative analyses of MFP). Based on this result, the NIR photometry method for firn core analysis has been improved (Aoki et al., 2013).

Using the $19-\mathrm{m}$ bore hole, temperatures at $10 \mathrm{~m}, 15 \mathrm{~m}$, and $19 \mathrm{~m}$ depths from the surface were measured using temperature loggers (Ondotori Jr. TR-51i, T\&D corporation), which were installed in the bore-hole and kept at 
each depth for one day (Table 2). In general, the temperature at $10 \mathrm{~m}$ depth was considered to be the annual mean temperature at the observation site, thus the mean annual temperature at SIGMA-A is considered to be approximately $-20^{\circ} \mathrm{C}$, while the measured annual mean air temperature from July 2012 to June 2013, which was calculated from the data of AWS in SIGMA-A, was $-19.3^{\circ} \mathrm{C}$.

\section{Glaciological observations in 2013}

\subsection{Snow-stake measurements}

A snow-stake network was established on July 24, 2013, in the same manner as the 2012 observations.

Table 2. Bore-hole temperatures measured in 2012.

\begin{tabular}{|c|c|}
\hline $\begin{array}{c}\text { Depth from } \\
\text { the surface } \\
(\mathrm{m})\end{array}$ & Temperature $\left({ }^{\circ} \mathrm{C}\right)$ \\
\hline 10 & -19.9 \\
\hline 15 & -20.0 \\
\hline 19 & -20.3 \\
\hline
\end{tabular}

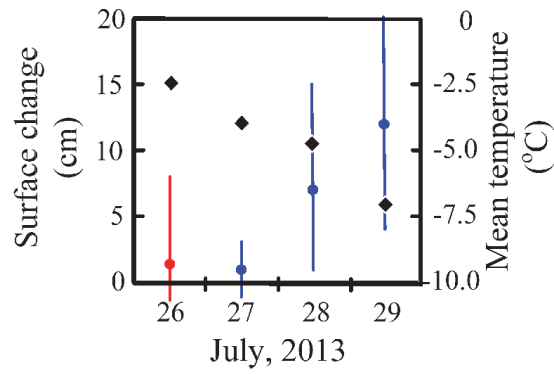

Fig. 12. Results of snow-stake observations in 2013.

Blue circles indicate the averaged surface lowering over all measurements from 9:00 a.m. of the previous day to 9:00 a.m. of the present day. Red circle indicates the averaged cumulative surface lowering from 9:00 a.m. on July 24 to 9:00 a.m. on July 26. Bars indicate the dispersion of the data. Black rhombuses indicate the mean air temperature at each observation interval.
Snow-stakes were inserted into the snow cover until they reached a thick ice layer, which was at approximately $120 \mathrm{~cm}$ below the snow surface (the average value was $117.3 \mathrm{~cm}$, with a standard deviation of $\pm 2.5 \mathrm{~cm}$ ). Each height from the snow surface to the top of the snow stake $(h)$ was measured each day at 9:00 a.m. from July 24 to July 29, 2013.

Fig. 12 shows the value of the surface change $\left(\Delta h_{\text {ave }}\right)$ $(\mathrm{cm})$, which is the surface change $(\Delta h)$ averaged over all the snow-stake data at each measurement. The dispersion of the data is also shown by bars. Here, the positive $\Delta h$ values indicate accumulation. Data from July 26 , which is shown in a different color, has a different measurement interval due to lack of data from July 25, namely, its value was derived from the cumulative data of 2 days, from July 24 to July 26 . The fluctuation of the mean air temperature during the observation intervals, which was measured at the AWS at SIGMA-A (Aoki et $a l ., 2014 \mathrm{a}$ ), is also shown in the figure. Because the mean air temperature values during the observation period were negative, the $\Delta h_{\text {ave }}$ values were positive, that is, accumulation occurred. The fluctuation of $\Delta h$ was much larger in 2013 than in 2012, which was probably caused by the redistribution of snow by a blowing snow event (Aoki et al., 2014a).

\subsection{Snow pit observation and snow sampling for chemi- cal analyses}

The observation period in 2013 was only one week long and the weather conditions were bad (Aoki et al., 2014a), thus snow pit observations and snow sampling for chemical analyses, which were performed in the same way as in 2012, were conducted only once, on July 27, 2013.

Fig. 13 shows the results of the snow pit observation and $\delta \mathrm{D}$ analyses. A pit was dug to a depth of $132 \mathrm{~cm}$ from the surface, in which a melt-freeze crust layer existed. We considered this layer to be the melted snow surface from the summer of 2012. The dry snow crystals were dominantly grain- shaped, although some thin ice layers were present. This result indicated that
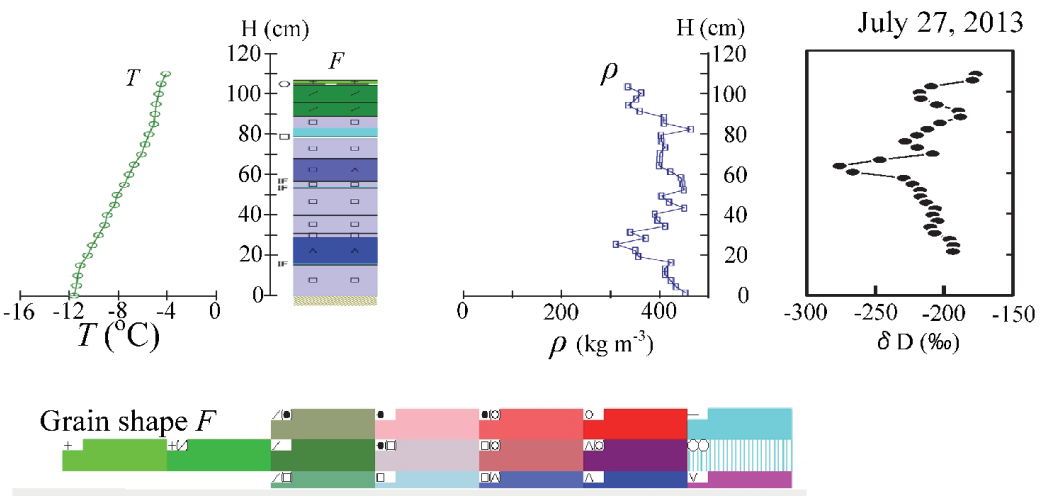

Fig. 13. Measurement results of snow pit observation and chemical analyses of snow obtained on July 23, 2013.

The colors and symbols representing snow classifications are in accordance with the snow classification system of Fierz et al. (2009). $\mathrm{F}$ is grain shape, $\mathrm{T}$ is snow temperature, and $\rho$ is wet density. 
significant snow melting had not occurred since the summer of 2012. Therefore, $\delta \mathrm{D}$ values showed a more obvious seasonal cycle in 2013 than in 2012, when the snow layer was affected by melt water (Fig. 10).

\section{Summary}

Glaciological observations were conducted in 2012 and 2013 at the SIGMA-A site on the northwest Greenland ice sheet $\left(78^{\circ} 03^{\prime} 06^{\prime \prime} \mathrm{N}, 67^{\circ} 37^{\prime} 42^{\prime \prime} \mathrm{W}, 1490 \mathrm{~m}\right.$ a.s.l.) as part of the SIGMA project. The meteorological conditions during the two observations were quite different: the meteorological condition in 2012 was warm, and heavy rainfall occurred during the observation period, while the meteorological condition in 2013 was cold, with a blowing snow event. These different meteorological conditions were reflected in the snow conditions: the snow condition in 2012 was very wet because of melting and rainfall, while the snow condition in 2013 was quite dry.

The glaciological observations in 2012 consisted of 1) snow-stake measurements, 2) snow pit observations, including observations of detailed grain size and specific surface area of snow measurement, 3) drilling of firn cores, and 4) snow sampling for chemical analyses. The glaciological observations in 2013 consisted of 1) snowstake measurements, 2) snow pit observations, and 3) snow sampling for chemical analyses.

The data reported in this paper should be helpful for understanding the glaciological conditions in the accumulation area of the northwest Greenland ice sheet and can be used to improve the snow physical model SMAP (Niwano et al., 2012) and to validate satellite-derived snow products for the SIGMA Project.

\section{Acknowledgements}

We thank the field campaign members of the SIGMA Project and GRENE-Arctic Project in Greenland in 2012 and 2013. This work was supported by (1) Japan Society for the Promotion of Science (JSPS), Grant-in-Aid for Scientific Research (S), number 23221004, (2) Green Network of Excellence (GRENE) Arctic Climate Change Research Project funded by MEXT Japan.

\section{References}

Akitaya, E. (1974): Studies on depth hoar. Contrib. Inst. Low Temp. Sci., Ser. A, 26. 1-67. http://hdl.handle.net/2115/20238.

Aoki, T., Hori, M., Motoyoshi, H., Tanikawa, T., Hachikubo, A., Sugiura, K., Yasunari, T. J., Strovold, R., Eide, H. A., Stamnes, K., Li, W., Nieke, J., Nakajima, Y., Takahashi, F. (2007): ADEOS-II/GLI snow/ice products: Part II - Validation results using GLI and MODIS data. Remote Sens. Environ., 111, 274-290. doi: 10.1016/j.rse.2007.02.035.

Aoki, T., Niwano, M., Yamaguchi, S., Motoyoshi, H., Kuchiki, K., Matoba, S. and Hachikubo, A. (2013): Optical measurements of snow and ice sample using near-infrared image sensors. Summaries of JSSI \& JSSE Joint Conference on Snow and
Ice Research 2013 in Kitami, 13 (in Japanese).

Aoki, T., Matoba, S., Uetake, J., Takeuchi, N. and Motoyama, H. (2014a): Field activities of the "Snow Impurity and Glacial Microbe effects on abrupt waring in the Arctic" (SIGMA) Project in Greenland in 2011-2013. Bull. Glaciol. Res., 32, http://dx.doi.org/10.5331/bgr.32.3

Aoki, T., Matoba, S., Yamaguchi, S., Tanikawa, T., Niwano, M., Kuchiki, K., Adachi, K., Uetake J., Motoyama H. and Hori M. (2014b): Light-absorbing snow impurity concentrations measured on Northwest Greenland ice sheet in 2011 and 2012. Bull. Glaciol. Res., 32, http://dx.doi.org/10.5331/ bgr.32.21.

Arnaud, L., Picard. G., Champollion, N., Domine, F. Gallet, C. J., Lefebvre. E., Fily, M. Barnola. M. J. (2011): Measurement of vertical profiles of snow specific surface area with a $1 \mathrm{~cm}$ resolution using infrared reflectance: instrument description and validation. J. Glaciol., 57(201), 17-29. http://www.igsoc. org:8080/journal/57/201/j10j080.pdf.

Box, J. E., Fettweis, X., Stroeve, J. C., Tedesco, M., Hall, D. K. and Steffen, K. (2012): Greenland ice sheet albedo feedback: thermodynamics and atmospheric drivers. The Cryosphere, 6, 821-839, doi: 10.5194/tc-6-821-2012.

Denoth, A., Foglar, A., Weiland, P., Mätzler, C., Aebischer, H., Tiuri, M., Shivola, A. (1984): A comparative study of instruments for measuring the liquid water content of snow. J. Appl. Phys. 56(7), 2154-2160. http://dx.doi.org/10.1063/ 1.334215 .

Fierz, C., Armstrong, L. R., Durand, Y., Etchevers, P., Greene, E., McClung, M. D., Nishimura, K., Satyawali, K. P., Sokratov, A. S. (2009): The International classification for seasonal snow on the ground. Technical documments in Hydrology (UNES CO document), 83, $80 \mathrm{pp}$. http://www.cryosphericsciences. org/products/snowClassification/snowclass_2009-11-23tagged-highres.pdf.

Fukuzawa, T. and Akitaya, A. (1993): Depth-hoar crystal growth in the surface layer under high temperature gradient. Ann. Glaciol., 18, 39-45. http://www.igsoc.org/annals.old/18/igs_ annals_vol18_year1993_pg39-45.pdf.

Gallet, J. C., Domine, F., Zender, C. S., Picard, G. (2009): Measurement of the specific surface area of snow using infrared reflectance in an integrating sphere at 1310 and $1550 \mathrm{~nm}$. The Cryosphere, 3, 167-182. doi: 10.5194/tc-3-1672009.

Grenfell, T. and Warren, G. S. (1999): Representation of a nonspherical ice particle by a collection of independent spheres for scattering and absorption of radiation. $J$. Geophys. Res., 104(D24), 697-709. doi: 10.1029/1999JD900496.

Hori, M., Aoki, T., Stamnes, K. and Li, W. (2007): ADEOS-II/GLI snow/ice products - part III: Retrieved results. Remote Sens. Environ., 111, 274-319, doi: 10.1016/j.rse.2007.01.025.

Hori, M., Aoki, T., Tanikawa, T., Kuchiki, K., Niwano, M., Yamaguchi, S. and Matoba, S. (2014): Dependence of thermal infrared emissive behaviors of snow cover on the surface snow type. Bull. Glaciol. Res., 32, http://dx.doi.org/10.5331/ bgr.32.33.

Jamieson, B. and Fierz, F. (2004): Heat flow from wet to dry snowpack layers and associated Faceting. Ann. Glaciol., 38, 187-194. http://dx.doi.org/10.3189/172756404781814762.

Johnsen, S. J., Dansgaard, W. and White, J. W. C. (1989): The origin of Arctic precipitation under present and glacial conditions. Tellus, 41B, 452-468, doi: 10.1111/j.1600-0889.1989. tb00321.x.

Kuchiki, K., Aoki, T. Niwano, M., Yamaguchi, S., Hachikubo, A., Takeuchi, Y., Hori, M., Tanikawa, T. (2013): Retrieval of snow grain size using optical measurements in near-infrared wavelengths. Summaries of JSSI \& JSSE Joint Conference on Snow and Ice Research 2013 in Kitami, 14 (in Japanese).

Langlois, A., Royer, A., Montpetit, B., Picard, G., Brucker, L., Arnaud, L., Harvey-Collard, P., Fily, M., and Goita, K. (2010): On the relationship between snow grain morphology and insitu near infrared calibrated reflectance photographs. Cold Reg. Sci. Tech., 61, 34-42. doi: 10.1016/j.coldregions.2010.01.004. 
Matzl, M. and Schneebeli, M. (2006): Measuring specific surface area of snow by near-infrared photography. J. Glaciol., 52(179), 558-564. doi: 10.3189/172756506781828412.

Mitchell, D. L. (2002): Effective Diameter in radiation Transfer General Definition, Applications, and Limitation. Journal of the Atmospheric Science, 59, 2330-2346. doi: 10.1175/1520-0469 (2002)059<2330:EDIRTG > 2.0CO;2.

Nghiem, S. V., Hall, D. K., Mote, T. L., Tedesco, M., Albert, M. R., Keegan, K., Shuman, C. A., DiGirolamo, N. E. and Neumann, G. (2012): The extreme melt across the Greenland ice sheet in 2012. Geophys. Res. Lett., 39, L20502, doi: 10.1029/ 2012GL053611.

Nihon Seppyo Gakkai (2010): Glaciological observation guidebook. Asakura Shoten, $136 \mathrm{pp}$.

Niwano, M., Aoki, T., Kuchiki, K., Hosaka, M. and Kodama, Y. (2012): Snow Metamorphism and Albedo Process (SMAP) model for climate studies: Model validation using meteorological and snow impurity data measured at Sapporo, Japan J. Geophys. Res., 117, F03008, doi: 10.1029/2011JF002239.

Ohmura, A. (2001): Physical basis for temperature-based meltindex method. J. Appl., Meteorol., 40(4), 753-761, http://dx. doi.org/10.1175/1520-0450(2001)040<0753:PBFTTB $>2.0$.CO;2.

Rignot, E., Velicogna, I., van den Broeke, M. R., Monaghan, A. and Lenaerts J. (2011): Acceleration of the contribution of the Greenland and Antarctic ice sheets to sea level rise. Geophys. Res. Lett., 38, L05503, doi: 10.1029/2011GL046583.

Stamnes, K., Li, W., Eide, H., Aoki, T., Hori, M. and Storvold, R. (2007): ADEOS-II/GLI snow/ice products - part I: Scientific Basis. Remote Sens. Environ., 111, 258-273, doi: 10.1016/j. rse.2007.03.023.

Steffensen J. P., Andersen K. K., Bigler M., Clausen H. B., DahlJensen D., Fischer H., Goto-Azuma K., Hansson M., Johnsen
S. J., Jouzel J., Masson-Delmotte V., Popp T., Rasmussen S. O., Röthlisberger R., Ruth U., Stauffer B., Siggaard-Andersen M. L., Sveinbjörnsdóttir A. E., Svensson A. and White J. W. (2008): Abrupt climate change happens in few years highresolution Greenland ice core data show abrupt climate change happens in few years. Science, 321, 680-684, doi: 10.1126/science.1157707.

Tedesco, M., Fettweis, X., Mote, T., Wahr, J., Alexander, P., Box, J. E. and Wouters, B. (2013): Evidence and analysis of 2012 Greenland records from spaceborne observations, a regional climate model and reanalysis data. The Cryosphere, 7, 615630, doi: 10.5194/tc-7-615-2013

van den Broeke, M., Bamber, J., Ettema, J., Rignot, E., Schrama, E., van de Berg, W. J., van Meijgaard, E., Velicogna, I. and Wouters., B. (2009): Partitioning recent Greenland mass loss. Science, 326, 984-986, doi: 10.1126/science.1178176.

Whitlow, S., Mayewski, P. A. and Dibb, J. E. (1992): A comparison of major chemical species seasonal concentration and accumulation at the South Pole and summit, Greenland. Atmos. Environ. 26A(11), 2045-2054, doi: 10.1016/09601686(92)90089-4.

Yamaguchi, S., Motoyoshi, H., Tanikawa, T. Aoki, T., Niwano, M., Takeuchi, Y. and Endo, Y. (2014): Application of snow specific surface area measurement using an optical method based on near-infrared reflectance around 900-nm wavelength to wet snow zones in Japan. Bull. Glaciol. Res., 32, http://dx.doi.org/10.5331/bgr.32.55.

Zuanon, N. (2013): IceCube, a portable and reliable instruments for snow specific surface area measurement in the field. International Snow Science Workshop Grenoble - Chamonix Mont-Blance- 2013 proceedings, 1020-1023. 